\title{
Individual variations of voluntary intake, feeding behaviour and development of the digestive tract in Holstein cloned growing bulls
}

\author{
R Baumont 1, A Détour 1, J Jamot 1, E Cellarier 1, Rt Jailler 2, \\ Rd Jailler 2, Y Geay 2, JP Renard ${ }^{3}$ \\ IINRA Station de Recherches sur la Nutrition des Herbivores ; 2INRA Laboratoire Croissance \\ et Métabolismes des Herbivores, 63122 St-Genès-Champanelle ; 3INRA Laboratoire \\ de Biologie cellulaire et moléculaire 78352 Jouy-en-Josas cedex, France
}

Individual variations of voluntary intake (VI) and feeding behaviour are quite high in ruminant animals (Dulphy et al, 1990, Ann Zootech, 39, 95-111). Experimental design like latin square takes into account these variations, but its use is not always possible. Does the use of cloned animals avoid the problem of individual variations?

Five male Holstein cloned calves were born at INRA Jouy en Josas (Chesné et al, 1993, C.R. Acad Sci Paris, Life Sciences, 316, 487-491). Then they were housed at INRA St-GenèsChampanelle, weaned at 4 months of age, fed individually hay and concentrate during 2 months and afterwards maize silage. At 10 months of age $(319 \mathrm{~kg}(S D=13.7))$ four animals (the two pairs of animals respectively born from two cows) were kept in digestibility crates and fed ad libitum once a day at $10 \mathrm{am}$ a complete diet ( $75 \%$ maize silage on drymatter basis). After 2 weeks of adaptation, VI, kinetics of intake and jaw movements were measured over 8 days (Baumont et al, 1990, J Agric Sci, 115, 277-284). Afterwards the animals were fattened with the same diet and slaughtered at 17 months of age. The weight of adipose tissue free digestive organs was obtained. In absence of a control group, individual variations in cloned animals were compared with those measured in groups of Charolais and Belgian-Blue (BB) bulls using the same experimental methods and with data of the literature.

Individual variations in cloned animals, expressed as the coefficient of variation (CV), were markedly low for VI, number of meals, and number of rumination periods. These low CVs were in accordance with the results obtained by Campling (1966, Brit J Nutr, 20, 25-39) who examined the variations of $\mathrm{VI}$ and feeding behaviour within 5 pairs of twin heifers. CVs of the total digestive tract and of the rumen weights were also markedly low in cloned animals. CVs measured on Charolais and BB bulls were all higher than on cloned animals and consistent with the results of Dulphy et al (1990, Ann Zootech, 39, 95-111). In conclusion, the use of cloned animals seems to be an interesting way to reduce the number of animals in feeding trials. It might be also helpful to understand the genetic component of the intake regulation.

\begin{tabular}{|c|c|c|c|c|}
\hline & \multirow{3}{*}{$\begin{array}{c}\text { Mean } \\
\text { value for } \\
\text { cloned animals } \\
99.5\end{array}$} & \multicolumn{3}{|c|}{ Coefficient of variation $(\%)$} \\
\hline & & \multirow{2}{*}{$\begin{array}{c}\text { Cloned } \\
3.2\end{array}$} & \multirow{2}{*}{$\begin{array}{c}\text { Charolais }(n=16) \\
9.0\end{array}$} & \multirow{2}{*}{$\begin{array}{c}\text { Normal BB }(n=6) \\
7.5\end{array}$} \\
\hline $\begin{array}{l}\text { Voluntary intake } \\
\text { (g DM/kg BW } 0.75 \text { ) }\end{array}$ & & & & \\
\hline Eating time $(\mathrm{min} / \mathrm{d})$ & 274 & 7.6 & 11.0 & 15.8 \\
\hline Number of meals $(/ \mathrm{d})$ & 18.9 & 4.6 & 19.0 & 14.9 \\
\hline Rumination time $(\mathrm{min} / \mathrm{d})$ & 454 & 4.3 & 10.2 & 11.2 \\
\hline Number of periods (/d) & 15.6 & 2.3 & 10.3 & 9.8 \\
\hline \multicolumn{5}{|l|}{ Weight of (g/kg empty BW) : } \\
\hline Empty digestive tract & 60.1 & 3.1 & 6.3 & 8.6 \\
\hline Empty rumen & 22.3 & 3.4 & 9.0 & 12.3 \\
\hline Empty intestines & 21.6 & 5.8 & 6.3 & 10.0 \\
\hline
\end{tabular}

